\title{
The Royal Entomological Society of London
}

$\mathrm{O}^{\mathrm{N}}$ May 3, 1833, a few enthusiastic entomologists met in the rooms at the British Museum then occupied by Mr. J. G. Children, at that time an official of the Natural History Department, and resolved to establish a society for the promotion of the science of entomology in its various branches. This was the inauguration of the body which, under the designation of the Entomological Society of London, has just completed a hundred years of useful and increasingly beneficial activity.

Previous attempts had been made to form an association with the same or similar objects, the first of which attempts can be traced to a date at least so early as 1745 , when an association, under the name of the Aurelian Society, is recorded to have held meetings at the Swan Tavern, Change Alley. This, however, and several other societies afterwards established with the like aims, had only an ephemeral existence; and it was reserved for the small company which met as stated on May 3, 1833, to found an organisation which, after passing through many vicissitudes and suffering many perils that seemed to threaten its very existence, has to-day reached a position of permanent security.

To this result many distinguished votaries of the science have, in their several ways, contributed. Among the original members of the Society was J. O. Westwood, to whom more than to any other person is due, as the present honorary secretary, Dr. S. A. Neave, says in the "History of the Entomological Society" which he has compiled with the assistance of the registrar, Mr. F. J. Griffin, and just published*, the successful growth of the enterprise during this early period Westwood was unremitting in his efforts for its welfare; the influence which he exercised in various official positions, including three periods as president, was most valuable; and in the jubilee year, 1883, his services met with due recognition by his unanimous election as honorary life president.

Those who knew Westwood recall with affectionate appreciation his genial and kindly nature, tempered with a touch of oddity, and his oldfashioned outlook on many scientific questions, not entirely unprejudiced, but never bitter. His association with Hope, one of the original officers, led to his appointment as keeper of the collection and library presented by Hope to the University of Oxford, and ultimately to his occupancy of the Hope professorship of zoology founded in 1861 .

The financial difficulties encountered by the Society in a critical period of its career might well have been fatal to its continued existence but for the generosity of J. W. Dunning, a fellow of Trinity College, Cambridge, whose gifts, many of

* The History of the Entomological Society of Jondon, 1833-1933. By Dr. S. A. Neave, assisted by F. J. Griffin. With an Introduction by Dr. E. B. Poulton, and a Financial Chapter by A. F. Hemming. Pp. xlvi $+224+8$ plates. (London: Entomological Society of London, 1933.) 10s. $6 d$. them anonymous at the time but now known to be his, included the whole expense incurred in connexion with the grant of the Royal Charter in 1885 and cannot have fallen far short of $£ 1,000$.

In the list of those who have occupied the presidential chair are found the names of Sir John Lubbock, afterwards Lord Avebury, Lord Wal. singham, F. Du C. Godman, R. Meldola, R. Trimen, N. C. Rothschild and Lord Rothschild. H. W. Bates was president in 1868-69, and was followed in 1870 by Alfred Russel Wallace, his associate in their famous journey to the Amazon. Bates again became president in 1878. Darwin was an original member, and was vice-president in 1838, but never filled the presidential chair.

Besides Westwood, the only other recipient of the honour of the life presidentship until the present occasion was the Rev. W. Kirby, joint author with W. Spence of the well-known "Introduction to Entomology". At the recent centenary celebration, Prof. E. B. Poulton, who succeeded Westwood as Hope professor at Oxford, was accorded the highest honour in the power of the Society to bestow, and became the third holder of the distinguished office of honorary life president. Prof. Poulton, who had held the presidentship on three separate occasions, was acknowledged by all to have advanced the cause of entomology in general and of the Society in particular more efficiently than any other living person. The introduction which he has furnished to the admirable "History" of the Society is a most interesting record of his memories of the Society over a period of fifty years, and includes some notable words both of warning and encouragement, the fruit of wide experience and ripe consideration. It was universally felt that he was, without any doubt, the right person to preside over the Society in this hundredth year of its existence, and his holding of the office is happily signalised by the Royal Command in accordance with which the Society has now the distinction of adding the word 'Royal' to its name.

It is interesting to note the various places in which, from time to time, the Society has found a home. The first general meeting after the founding of the Society in J. G. Children's quarters at the British Museum took place at the Thatched House Tavern, St. James's Street; but before the end of the year a fresh domicile was acquired at 17 old Bond Street. Here the Society remained until 1852, when it removed to 12 Bedford Row. Some years after this, an arrangement was made by which the library was left at Bedford Row, but the meetings were held by the hospitality of the Linnean Society in the latter's rooms at Burlington House. In 1874 a proposal was set on foot for an amalgamation of the two Societies ; but difficulties arose about the accommodation of the library, and the scheme fell through. In 1875 a home was found 
for the entomologists at 11 Chandos Street, quarters which they occupied as tenants of the Medical Society of London, until in 1920 the present house, 41 Queen's Gate, was bought and in the course of the next few years was gradually adapted for all the purposes of the Society.

That this solution of the housing difficulty became possible was due to the exertions and generosity of many of the Society's members, and especially to the untiring activity and skilful management of W. G. Sheldon as honorary treasurer. The house in its present condition must strike every visitor as being excellently fitted for its purpose. The library, which occupies the whole of the first floor, contains the extremely valuable collection of books belonging to the Society, well arranged in substantially constructed bookcases and adequately catalogued. There are a council room and commodious offices on the ground floor, but the chief glory of the house is the new lecture room, which has been built on the basement level at the back of the property. This is a remarkably handsome structure, well-proportioned and suitably furnished; but what gives it its main distinction is the oak-panelled interior and finely moulded ceiling, the latter a reproduction of the work in the Bromley Room at the Victoria and
Albert Museum. These features, together with the presidential chair and desk, structures worthy of their surroundings, were provided by $\mathrm{Mr}$. R. W. Lloyd, a fellow of the Society, entirely at his own expense.

On the walls of the rooms and staircase at Queen's Gate hangs an interesting collection of portraits of prominent fellows of the Society ; and in one of the ground-floor rooms is a large painting by J. Cooke, "The Aurelians", depicting Dr. G. B. Longstaff, a keen and travelled entomologist and generous benefactor to the fund for the purchase of the Queen's Gate House ; and his friend Selwyn Image, also an enthusiastic entomologist and sometime Slade professor of fine art in the University of Oxford.

The celebrations of the Society's centenary lately held were attended by a large number of delegates from the British Empire and from foreign countries. The proceedings included a general meeting on May 3, when speeches were made and addresses presented, a scientific conversazione at Queen's Gate, a reception by the trustees of the British Museum, a supper at the Gardens of the Zoological Society of London, excursions to Tring and to Whipsnade, and a reception by His Majesty's Government at Lancaster House. F. A. D.

\section{'Red Coal'}

$\mathrm{M}^{\mathrm{A}}$ AN is unceasing in his quest for powersocial, political and mechanical. In his search for sources of mechanical power, which, with a charming allegiance to the past, is still associated with the horse when it is measured, man has dug deep mines to bring 'black coal' to the surface and learned how to convert energy into steam and electricity. He has harnessed the waterfall_-'white coal'- - to the same end, making it swiftly turn a wheel, a turbine, and put areas containing only rivers on an equality with those perched on top of the coalfields. In one favoured district he has dared those forces of the inner earth which manifest themselves as volcanoes, or in their milder form as fumaroles, and tamed their steam to pass through turbines and generate electricity, which may be regarded as produced from 'red coal'.

The story of this achievement, largely that of Prince Ginori Conti and his devoted band of helpers, is a thrilling one: it has in part been told in these columns by him (Nature, 121, 59, Jan. 14, 1928), and it has been brought up to date in a lecture delivered by him before the Royal Society of Arts on May 3.

Originally the enterprise was a chemical one to exploit the boric acid contained in the lagoni discovered by Höfer in 1777, and begun by Larderel in 1818; for fully fifty years, Tuscan boric acid was practically without a competitor in the world's markets. To-day the use of the steam to produce electricity is the important activity, and to-morrow it may well be that the amount of cheap power produced in this way will have a deciding effect on the progress of Italian industry.

Three factors have contributed to the advance : the gradual development under Prince Ginori Conti's leadership of a technique for steam drilling ; the fact that the wells maintain a steady head of steam and are not intermittent like the geysers in Yellowstone National Park; and the development of turbines of the free exhaust type.

The rotary or percussion systems of drilling, or both alternatively, are used; for the soffioni steam is often found at a depth of $100 \mathrm{ft}$. and, as the jet increases in volume, drilling becomes more difficult. There comes a moment when the steam gains the upper hand and an explosion takes place with the expulsion of stones and mud and a deafening noise which goes on for weeks and can be heard for several miles. The biggest well, completed in 1931, has an output of $440,800 \mathrm{lb}$. of steam per hour at a pressure of 3.5 atmospheres with a temperature of $205^{\circ} \mathrm{C}$. A second large well completed a year after has an hourly output of $396,000 \mathrm{lb}$. of steam.

The total output of steam from all the wells of the district is now estimated at more than two million lb. per hour. Only a portion is utilised for feeding the power plants; these are yielding continuously $12,000 \mathrm{kw}$. for which there is a regular demand. Now that confidence in the trustworthiness of the supply has been obtained, the amount of power generated may be expected to increase rapidly. 